\title{
LA VIDA TRASTOCADA. EL SENTIDO DE LA PANDEMIA EN ESTUDIANTES DE EDUCACIÓN SUPERIOR
}

- JOSÉ ANTONIO SERRANO CASTAÑEDA

https://orcid.org/0000-0002-7272-7001

Universidad Pedagógica Nacional

\section{LORENA DEL SOCORRO CHAVIRA ÁLVAREZ}

https://orcid.org/0000-0002-3575-7076

Universidad Pedagógica Nacional

JUAN MARIO RAMOS MORALES

https://orcid.org/0000-0002-5364-1827

Universidad Pedagógica Nacional

RESUMEN El presente trabajo muestra un conjunto de reflexiones enlazadas al proyecto de investigación "Procesos curriculares y prácticas de acompañamiento" (PCyPA) relativas a los efectos de la pandemia en estudiantes de nivel superior. En primer lugar, exponemos algunas problemáticas relativas a dar cuenta del presente a través de algunas temáticas como demanda social, acontecimiento, memoria, testigo. Más adelante, describimos el proceso de ser tutor acompañante en el programa Entre pares, que tiende a crear comunidades de aprendizaje relativas a la literacidad en educación superior, proyecto que nos ha permitido producir material narrativo. Continuamos con la exposición de principios básicos del trabajo narrativo que, como telón de fondo, apuntala nuestra trabajo formativo e indagatorio. En la tercera parte, exponemos el sentido que estudiantes dan al vivir en la pandemia a través de tres apartados: el saber caótico del virus; el Covid en casa y mu/danzas en la vida cotidiana y en las trayectorias formativas. Cerramos con algunas reflexiones sobre la pandemia en el mundo y en específico sobre el sentido que los estudiantes otorgan a la experiencia vivida.

Palabras clave: Investigación narrativa. Coetaneidad. Educación superior. Pandemia. Covid-19. 


\section{PANDEMIC IN HIGHER EDUCATION STUDENTS}

This work shows a set of reflections linked to the research project "Curricular processes and accompanying practices" (PCyPA), is focused to the effects of the pandemic of Covid in higher-level students. First, we expose some problems related to tell of the present history through some themes such as social demand, event, witness, memory. Later, we will describe the process of being an accompanying tutor in the Peer-to-Peer project, which can create learning communities affected by literacy in higher education, the program that has allowed us to produce narrative material. It continues with the exposition of basic principles of narrative work that, underpins our formative and investigative work. In the third part, we explain the sense that students live in the pandemic through very different sections: the chaotic saber of the virus; Covid at home and changes in daily life and in training paths. We close with some reflections on the pandemic in the world and specifically about the meaning that students give to the lived experience.

Keywords: Narrative research. Coetaneity. Higher education. Pandemic. Covid-19.

\section{RESUMO A VIDA TRASTOCADA. O SIGNIFICADO DA PANDEMIA EM ESTUDANTES DE ENSINO SUPERIOR}

Este artigo mostra um conjunto de reflexões vinculadas ao projeto de pesquisa "Processos curriculares e práticas de acompanhamento" (PCyPA) relacionadas aos efeitos da pandemia em estudantes de nivel superior. Em primeiro lugar, apresentamos alguns problemas relacionados ao tempo presente por meio de temas como demanda social, evento, memória, testemunha. Posteriormente, descrevemos o processo de acompanhamento do programa "Entre Pares" que tende a formar comunidades de aprendizagem relacionadas à alfabetização no ensino superior, projeto que nos permitiu produzir material narrativo. Continuamos com a exposição de princípios básicos do trabalho narrativo que sustentam nosso trabalho formativo e investigativo. Na terceira parte, explicamos o significado que os alunos dão à vida na pandemia por três seções: conhecimento caótico do vírus; o Covid em casa e transformações na vida cotidiana e nas trajetórias formativas. Concluímos com algumas refexões sobre a pandemia no mundo e, especificamente sobre o significado que os alunos dão à experiência vivida.

Palavras-chave: Pesquisa narrativa. Coetaneidade. Ensino superior. Pandemia. Covid-19. 


\section{Introducción}

Este artículo se desprende del proyecto de indagación titulado "Procesos curriculares y prácticas de acompañamiento". Se liga a una serie de reflexiones efectuada sobre el asunto de las prácticas de literacidad -sustantivamente focalizado- en el inicio de la vida universitaria.

El texto está organizado en tres secciones. De inicio, reflexionamos sobre un tema de actualidad: la pandemia en el mundo y -en específico- cómo estudiantes de nivel superior dan sentido a los meses que llevamos resguardados como medida de disminución de los contagios. De ahí que deliberamos sobre lo que es documentar la coetaneidad -algunos historiadores denominan historia del presente- que apuntalan el trabajo efectuado por el Gobierno mexicano en el marco de la emergencia sanitaria producida por la pandemia del SARS-CoV2. Más adelante, mostramos el soporte con el que hemos trabajado: la perspectiva biográfica-narrativa. En ésta, hemos apuntalado la producción y estructuración del material que nos permite dar cuenta del sentido que tiene para los estudiantes continuar con su proyecto formativo en el contexto actual de emergencia sanitaria.

La tercera parte expone la organización del material producido (por estudiantes de la licenciatura en Administración Educativa de la Universidad Pedagógica Nacional) a partir de la suspensión de actividades en el sistema educativo nacional, en especial en las instituciones de educación superior. Organizamos las narrativas de treinta y ocho estudiantes en tres categorías: el saber caótico del virus; el Covid en casa y mu/danzas en la vida cotidiana y en sus trayectorias formativas. Cerramos el texto con algunas reflexiones alrededor de la pandemia, la escolarización y el contexto, así como el papel de la narrativa para documentar la historia del presente (ARÓSTEGUI, 2004).

\section{Documentar la coetaneidad}

Entre otros, la historia de la humanidad ha dedicado capítulos a los desastres y a las enfermedades que la han acompañado. Las modalidades de organización de la información están relacionadas con el espíritu de la época y con objetos materiales posibles, lo que ha permitido a Debray señalar que la humanidad ha atravesado "las diferentes eras técnicas de la memoria: literal, analógica y digital" (1997, p. 34).

La pandemia es un hecho actual. Documentar el presente nos pone en la mira de pensar qué es hacer historia de lo vigente, de los coetáneos. El presente pertenece a la inmediatez que todo ser humano tienen en su mundo-de-vida. Al respecto Husserl afirma: “El mundo no es lo que yo pienso sino lo que vivo... por estar en el mundo estamos condenados al sentido; y no podemos hacer nada, no podemos decir nada, que no tome un nombre en la historia" (HUSSERL, 1989, p.16). El mundo de vida es el mundo presente -de los coetáneos- de nuestra acción cotidiana, como mundo heredado por nuestros antecesores. A la vez, estamos irremediablemente volcados a transformarlo y presentarlos a los sucesores en tanto mundo con sentido culturalmente producido. El presente, con un calado muy diverso, anuda la dialéctica entre antecesores, coetáneos y sucesores.

Para que se produzca historia del presente habrá que transmutar la experiencia vivida por los actores sociales en historia escrita. La historia del presente no es la recolección de hechos, descripción de los eventos o sumatoria de éstos. Vale más centrar la historia del presente a lo que estamos condenados en tanto seres humanos: a dar cuenta del sentido que los actores generan ante los eventos sociales y naturales (GRONDIN, 2014). Sentido que está organizado -como un rompecabezas- de di- 
versos hilos, texturas y fuentes que encuentran en el actor social cierta disposición para anudar lo que el contexto dispone. Lo que en la vida social enlaza a los sujetos no es tanto el hecho, sino el sentido compartido/diferenciado que le otorgan a la realidad objetiva en íntima conexión con las particulares trayectorias biográficas (DELORY-MOMBERGER, 2009). La historia del presente consiste en mostrar el sentido de los actores sociales en lo que evanescentemente denominamos actualidad. La historia del presente se interroga por el sentido de la experiencia vivida, además requiere de demandas sociales, del acontecimiento, de memoria, de testigos (DELACROIX, 2018), a los que dedicaremos algunas palabras.

Demanda social. La emergencia sanitaria actual ha mundializado los asuntos que percibíamos como más cercanos a nuestra vida común: el tacto, la cercanía con el otro, la confianza en el prójimo, la cercanía con desconocidos en los lugares públicos. Elaborar saber sobre el presente para diseñar estrategias de supervivencia está a la orden del día. Lo que vivimos en la actualidad como emergencia sanitaria nos compele a dar cuenta del presente pandémico -demanda social-, lo que conlleva cierta dosis de implicación y mirada restringida de analizar el sentido socialmente producido como si lo viera otro, con su consecuente mirada reflexiva y con la perspectiva de que la información producida esté en condiciones de generar, a diferentes escalas, un beneficio social. Documentar la experiencia afecta tanto a las políticas públicas (en el ámbito de la salud, de la ciudadanía, de la economía, de la educación, de la diversidad -del aprendizaje, social, de género- por ejemplo) (DIETZ, MATEOS, 2020), como a la vida comunitaria próxima (construir nuevas formas de vínculo social, de ciudadanía, del cuidado del otro), sin dejar de vislumbrar las secuelas en la vida personal (cuidado de sí y de los nuestros los co-pre- sentes, de la respuesta a las nuevas formas de educación).

Acontecimiento. Dar cuenta del presente también nos hace preguntarnos sobre el objeto-acontecimiento: el vínculo contemporáneo entre humanidad y naturaleza en la particularidad de un asunto biológico que nos pone en vilo: la desaparición de individuos, de grupos familiares con diversos niveles de proximidad por un objeto no perceptible. En la vida con otros hemos dado sentido a la muerte individual, pero no lo habiamos percibido con tanta rapidez, simultaneidad y cercanía en tan variadas geografias. Es la primera vez que la humanidad asiste por diversos medios electrónicos a la propagación al pie de la letra de una epidemia que no atiende de manera especial a países, clases sociales o individuos (si bien es cierto que sus efectos nocivos se concentran en los adultos mayores y en personas con comorbilidades). El virus es democrático, no excluye individuos ni razas ni credos ni género ni zonas geográficas ni climas.

En conjunto, el mundo vive un experimento mundial en diversos estancos: la confección de estrategias para comprender el funcionamiento biológico del virus y el diseño de una vacuna - la égida la lleva la genética-; la confección de tácticas sociales de prevención -desde el confinamiento a la contaminación masiva-, con la idea de "guerra" como metáfora para hacer frente al virus; la explicación individual/ social producida por la existencia del virus como invento o producción en laboratorio-, entre otros. El imaginario está en juego en la vida social sobre un objeto que no percibimos, pero detectamos sus efectos. Un objeto hiperperfeccionado “descendientes de células que habrían evolucionado liberándose del molesto material de la reproducción para reducirse a la expresión más simple y conseguir la mayor eficacia... Se habrían simplificado para llegar a su mínimo vital" (REEVES, DE ROSNAY, COPPENS, 
SIMONNET, 1998 p. 53). El virus es un parásito en búsqueda de vida para reproducirse.

De acuerdo con Harari, las epidemias no requirieron del mundo globalizado para esparcirse; en la historia mundial tenemos noticias de epidemias más allá de las fronteras de países. Al sobrepasar las fronteras, "La cosa más importante que las personas precisan comprender sobre la naturaleza de las epidemias tal vez sea que su propagación en cualquier país pone en riesgo a toda la especie humana" (HARARI, 2020, p. 4, subrayado del autor). Así, el objeto pandemia tiene múltiples aristas para la población. Los ciudadanos se enfrentan a la comprensión de un objeto para el cual poco estaban habituados, para ellos en corto tiempo se ha ampliado el tesoro lingüístico -algunos locales y otros de uso trasnacional- para dar cuenta de un evento que casi reduce a la nuda vida a la humanidad (AGAMBEN, 1995).

En un mundo actual lleno de efigies, por diferentes vías ha aparecido una amplia iconografía sobre el virus. En el inicio de la pandemia circularon imágenes de muy diversa procedencia: ciudades vacías por el confinamiento; cápsulas de aislamiento; la elaboración de mascarillas por artesanos o en máquinas 3D; hoteles, campos deportivos -u otros espacios- transformados en salas hospitalarias; hileras de ataúdes en improvisados camposantos; personal de salud en evidente muestra de cansancio; muertos en las calles de poblados; hospitales asaltados por habitantes que piensan que la epidemia la propaga el Estado para desaparecer a sus futuros pensionados, entre muchas otras. La que más sobresale es la producción iconográfica del anonimato producida por la incorporación en nuestro cuerpo de las mascarillas. Al momento, el mercantilismo muestra una de sus facetas; se inundó el espacio social de producción de mascarillas, de artículos para evitar la propagación del vi- rus. A la vez, la representación se multiplicó en imágenes para divulgar por qué el nombre de coronavirus. Memes, bulos y fake news hicieron acto de presencia. La iconografia porta una forma de saber que tiene efecto en la comprensión de la pandemia, la generación de nuevos hábitos y sus consecuencias para la vida en común.

El ámbito lingüístico explosionó. El vocabulario que circula incluye nuevos significantes: los nativos del ámbito científico (SARS-CoV2, COVID19, pandemia, epidemia, Células T); de los procedimientos médicos (intubado); algunos derivados de medidas sanitarias para la población ("Susana distancia", estornudo de etiqueta); unos más procedentes del ámbito epidemiológico (casos totales, recuperados, portadores, portadores activos); otros de medidas políticas de planeación social (semáforos, fases, desescalada, municipios de la esperanza); no dejaron de aparecer los relativos al orden legal de cada país (decretos, bandos, autoridades sanitarias federales, estatales, municipales). La extensión de términos ha sido implacable. Las acciones comunitarias han sido diversas: poblaciones con usos y costumbres que han cerrado las vías de propagación del virus; poblaciones con usos y costumbres que poco han asumido para contener la epidemia local. Por países, el sentimiento social hacia el personal de enfermería ha sido variopinto: del reconocimiento -a veces con honores- a la agresión física y verbal -por considerarlos portadores, culparlos de infectar a otros o incluso de fallecimientos-. En el mismo fardo está el manejo grupal del virus: poblaciones que se acogen a procedimientos naturales hasta las que asumen los preceptos científicos para atenderse. En síntesis, el objeto-acontecimiento es múltiple y de difícil aprehensión para el conjunto de los sujetos que viven la pandemia; los sentidos son diversos y a diversa escala. 
Memoria. En nuestras culturas, la memoria tiene carácter fundante. En la mitología griega Mnemosine, personificación de la memoria, es la madre de las nueve musas que en nuestro imaginario son danzantes y cantantes, pero que en la cosmología griega formaban parte de la explicación metafórica de algo más profundo, la naturaleza humana. Las musas "presidian el Pensamiento en todas sus formas: elocuencia, persuasión, sabiduría, Historia, Matemáticas, Astronomía" (DE LA IGLESIA, s/f. p. 367). Musas que, explicitadas en el trívium y el cuadrivium, llevaron a la estructuración de proyectos formativos. La historia ha conservado el texto de Félix Mineo Marciano Capella dedicado a su hijo con el fin de mostrar el saber universitario de su época (siglo V). La obra describe la presentación de las musas en la boda entre Mercurio y Filología; “En el principio fue el verbo, lo que coloca a Gramática en el inicio de los saberes" (DE LA IGLESIA, s/f, p. 131). Gramática se presenta ante ellos y dice: "durante mi niñez nunca tuve otra tarea distinta a la de leer y escribir correctamente, pero ahora tengo otras obligaciones añadidas: la del correcto entendimiento y la de la crítica erudita de todo cuanto se expresa por medio de la palabra" (DE LA IGLESIA, s/f, p. 133). Es la memoria literal.

Memoria es el mecanismo que nos permite organizar los recuerdos. La etimología de recuerdo está relacionada con el corazón; recordar es "volver a pasar por el corazón" (DE, 30/06/2020). El recuerdo no es evocación de una imagen ni traer el objeto a la conciencia ni volver a presentar al objeto al alma. En todo caso, es poner en acto lo que nuestro ser en su conjunto trae al presente. Implica un efecto de tamiz alejado de los cánones epistemológicos o cognitivos. Recordar es una selección que es producto de nuestra historia individual arropada en la vivencia colectiva. Al formar parte de la vida en común, el recuerdo es una cons- trucción social, producido por los mecanismos propios del espíritu de la época. En la actualidad contamos con diversos mecanismos organizados para favorecer el recuerdo en las trayectorias escolares e impulsar varios tipos de organización de la memoria (literal, analógica, digital).

Vale también añadir que la edificación de la memoria es una construcción cultural organizada en instituciones -al normar vínculos entre grupos- que elaboran diversas estrategias - de recolección, organización y difusiónordenadas bajo cierta logística para encausar la acción práctica de los sujetos y disponer del sentido de lo recordado. Al paso viene la gramática; leer y escribir en nuestra vida moderna se muestran como saber legítimo en un espacio concreto, la institución escolar. La escuela - guardiana inicial de la escritura y de sus normas- edifica trayectorias que impactan la vida individual y grupal. Leer y escribir nos forma como sujetos sociales; nos vinculan con presentes y ausentes -formamos parte de tradiciones-; nos permiten designar a los objetos de nuestro mundo -conforma nuestro tesoro lingüístico-; organiza y da nombre a los sentidos y sentimientos - la ética y la estética-. Nuestra armazón lingüística nos da un lugar en el mundo y nos permite dar cuenta de él. Dar cuenta de la vida presente nos remite a la historia de la humanidad, colectiva e individual, expresada en las producciones materiales (escritura) sobre los fantasmas que recorre la humanidad/grupo/individuo respecto a las pandemias.

Testigo. Testigo y testimonio están unidos en la edificación del saber histórico. El sujeto que cuenta historias se sitúa en un mundo simbólico que le preexiste. Bajo la espalda del recién nacido está - por extensión- la historia de la humanidad y -de forma particular - la cultura concreta: es una voz posible que expresa, por diversos medios, cierta forma de 
ser, del ser social. Los actores sociales han construido saber sobre las epidemias y se han imaginado formas de lidiar con el padecimiento, el dolor, la muerte.

La historia de la humanidad es posible con la articulación de dos caras de la misma moneda: la materia organizada (la naturaleza transmutada por los humanos, el soporte material) y la organización materializada (la impronta del sentido socialmente elaborado por las culturas particulares a lo largo de la historia de la humanidad en materiales tangibles - previamente transformados de la naturaleza- para cumplir una finalidad cultural). Del lado de la materia organizada se encuentran las formas en que se organiza la comunicación: los "modos semióticos (el tipo de signo utilizado: texto, imagen o sonido), del dispositivo de difusión... del soporte físico (piedra, madera, papiro, papel, ondas), así como los medios de transporte de los hombres y de los mensajes" (DEBRAY, 1997, p. 28) las cursivas son del autor). Materia organizada se refiere a la producción material que ha permitido que el saber de los hombres sobre sus objetos (reales, imaginarios) permanezca para, luego, ser interpretados por otros. Un ejemplo lo tenemos en las pinturas rupestres: se modifica la naturaleza se emplea un modo semiótico bajo un soporte físico, con algún sentido para los coetáneos; un sentido abierto a los sucesores. La materia organizada es la transformación de la materia natural que hace circular el saber de la aventura humana a lo largo del tiempo.

Por otro lado, la organización materializada se refiere a la institución cultural que cobija lo materia dispuesta para dar sentido a lo que se objetiva en los instrumentos producidos. Están los sistemas culturales que se organizan de múltiples formas bajo "configuraciones comunitarias, a saber, las diversas formas de cohesión que unen a los operadores humanos de una transmisión (o más exactamente, im- puestas a ellos por la naturaleza material de los signos y dispositivos utilizables)" (DEBRAY, 1997, p. 29), las cursivas son del autor). Se refiere al saber instituido por los grupos sociales que permite encontrar sentido de lo que se intenta transmitir a un determinado grupo. La escritura en un papiro (materia organizada), por ejemplo, al incluir personajes muestra acciones, disposiciones sociales, normas, valores y principios estéticos con algún sentido para los que comparten el sentido expuesto en la materia organizada. Todo material producido se hizo bajo la idea de-para-nosotros que habitamos el presente - con variabilidad de sentidos-, pero siempre con sentido abierto para los sucedáneos.

La articulación materia organizada-organización materializada se anuda en los sentidos producidos por los testigos-testimonios de la humanidad en relación con las enfermedades, las epidemias. Huremovic (2019a) advierte que el enfrentamiento con las enfermedades infecciosas ha moldeado la historia de nuestras sociedades y culturas. Los brotes pandémicos han diezmado a poblaciones enteras incluso con más efectos que las guerras entre los pueblos. El contacto de las enfermedades ha creado nichos en el ámbito de las ciencias, como sería el caso de la psiquiatría y del nacimiento del psicoanálisis. En nuestra tradición judeocristiana las pandemias se encuentran en el origen de religiones o grupos sociales y el final - por venir- de la humanidad. Del griego y del latín nos llegan las palabras, plaga, peste, epidemia y pandemia, pero los modos de explicación han cambiado (y se ha universalizado el latín para denominar los objetos causantes).

Tucídides -en su recuento de la guerra del Peloponeso- es el primero en dar cuenta de las plagas sin intervención divina. A lo largo de la historia, el recuento de las plagas es largo: Antonina, Justiniana, la muerte negra (originada en China y por el camino de la seda llega a 
Europa), por mencionar las más antiguas. Su documentación nos ha permitido advertir que la globalización de las epidemias no es un hecho reciente, forma parte del intercambio social.

Los instrumentos de trabajo para atender las enfermedades infecciosas se han sofisticado en el campo médico; no obstante, la estrategia para evitar la propagación se ha refinado con base en el principio de la distancia social: solución expuesta en el Viejo Testamento (Levítico) y con medidas sociales concretas como la cuarentena. El término cuarentena

tiene una larga historia, ha sido introducida como medida de salud pública durante la peste negra en 1377 en la ciudad-estado de Dubrovnik (antes Ragusa) al hacer que los que llegaban estuvieran un periodo de 30 días (treintena) en la isla cercana de Lokrum. Este método fue adoptado por otras ciudades-estado marítimas de la época (p.e. Venecia, Génova) y el periodo fue extendido a 40 días (cuarentena). (HUREMOVIC, 2019b, p. 86)

El enlace que hemos forjado de testigo-testimonio es para evitar la disputa sobre la noción del sujeto de la historia (FUENTES, 2007). En todo caso nos interesa resaltar el hecho de que la documentación a la que en el momento actual le damos de histórica no tenía, en el momento de su elaboración, la finalidad expresa de inscribirse en esta serie. Vale destacar que la historia se hace con la producción material confeccionada por la humanidad (relatos, cuentos, mitos, literatura, manuales del hacer práctico, textos relativos a las organizaciones jerárquicas de instituciones -un largo etcétera entraría aquí-). En su conjunto, a través de los materiales producidos estamos en condiciones de dar cuenta de los modos de ser de la actividad práctica -y de los sentidos edificados por el contacto con enfermedades y sus mitologías- que ha permitido a los seres humanos construir los esquemas de acción que los orientan en la vida común. Al respecto, Bourdieu señala que "las prenociones del sentido común... contribuyen a construir la realidad que evocan" (BOURDIEU 1997, p. 129). En este sentido, nos interesa trabajar con las expresiones de "sentido común" pues en su confección develan el saber adquirido por los coetáneos -en la dialéctica del pasado, presente y futuro- para comprender y dar sentido a la vida del presente -la propia, la de los otros cercanos y distantes-.

Con apoyo de los materiales producidos por los actores sociales de la época, Duby (1989) reconstruyó la visión del mundo del año mil en Europa. Se apoyó en diversos tipos de materiales, tanto los producidos por los pocos letrados en latín que existían, como por las evidencias antropológicas que se encuentran. En el rescate de las fuentes también entran aquellas expresamente dedicadas a documentar lo que acontece en la época para dar a conocer a Dios lo que el hombre ha confeccionado en este mundo. El abate de Cluny supone un Dios lector de los acontecimientos humanos. "Buenas o malas, todas las acciones que se producen en el mundo por la voluntad o el permiso de Dios deben servir a la gloria y la edificación de la Iglesia. Pero si no se las conoce, ¿cómo pueden contribuir a alabar a Dios y a edificar la Iglesia? Escribir la historia es, por tanto, necesaria" (DUBY, 1989, p. 16). El paso del tiempo ha dado nuevas estrategias de descripción de las enfermedades a la vez que se han focalizado los sectores donde aparecen. El primer libro de esta índole es el de Ramazzini (1743/2011) que vincula tipos de enfermedades y actividades sociales. Su libro (De Morbis Artificum Diatriba. Tratado sobre las enfermedades de los trabajadores) lo lleva a ser considerado el padre de la medicina del trabajo. Expone nuevos objetos de comprensión en una época de naciente trasformación hacia el mundo burgués (la atención hacia en- 
fermedades de gremios). El texto aventura una nueva mentalidad sobre las enfermedades, su etiología y los modos de explicación originados por una nueva visión del cuerpo humano cuya base está en la naciente idea de ciencia, sus deliberaciones proyectan un modo diverso de la comprensión de las enfermedades. Para el caso, nos centraremos en la materia organizada-organización materializada producida a partir de los relatos de los estudiantes, una forma de ser testigos en el tiempo presente de los efectos de la pandemia, que como sus predecesoras tendrá efectos en diversos planos: individuales, grupales, sociales, culturales, económicos y políticos.

\section{Promover la literacidad}

\section{académica en educación superior}

Con apoyo de Secretaría Académica, desde 2017 en la Universidad Pedagógica Nacional (UPN) se dio cause a un proyecto institucional - bajo el título Entre pares- que diseñó estrategias de acompañamiento entre alumnos de cursan el final de la carrera (Educación indígena, Pedagogía, Psicología Educativa, Intervención Educativa, Sociología de la educación, Administración educativa) y con alumnos de recién ingreso a la institución. El diseño de la estrategia se funda, por un lado, en el apuntalamiento de la idea de acompañamiento sostenida en los planteamientos de comunidades de aprendizaje (WENGER, 2001) y, por otro, en las nociones expresadas en los nuevos estudios de literacidad que, con base en las supuestos de Vigotsky, han promovido dos perspectivas. En primer lugar, los estudios que «toman como unidad de análisis al individuo (o sujeto social) y sus prácticas; en segundo, los que toman como unidad de análisis a la comunidad local y sus recursos» (HERNÁNDEZ-ZAMORA, 2014, p. 255). En algunos periodos institucionales la UPN convoca a alumnos -con más del 70\% de créditos en sus respectivas licenciaturasque estén interesados en realizar su servicio social en el proyecto Entre pares; el proyecto contempla dos fases (de capacitación y tutoría par). Cabe adicionar que hay periodos de encuentro presencial y virtual en las dos fases para valorar el trabajo efectuado, en el camino buscamos soluciones o alternativas a las eventualidades presentadas por los integrantes del proyecto.

Incluidas las dos fases, el proceso de documentación al interior del proceso formativo del programa Entre pares y la del proyecto de indagación Procesos curriculares y prácticas de acompañamiento se apuntala en la perspectiva cualitativa, principalmente bebemos de las aguas de las tradiciones biográfico-narrativas (SUÁREZ, 2007; DELORY-MOMBERGER, 2009; CONTRERAS y PÉREZ DE LARA, 2010; SOUZA, SERRANO, RAMOS, 2014; SERRANO, RAMOS, BALLESTEROS, TRUJILLO, 2015; BOLIIVAR Y DOMINGO, 2019; PASSEGGI, 2020).

Nuestra perspectiva de trabajo se desprende de los supuestos de investigación narrativa planteados por Connelly y Clandinin (1995) quienes retoman la versión de Dewey sobre experiencia. En primer lugar, entendemos la experiencia como el movimiento que permite la aprehensión cualitativa del mundo (DEWEY, 2008; EISNER, 1998; VAN MANEN, 2003); da lugar al establecimiento de significados de la interacción con el mundo natural y cultural. En segundo lugar, la experiencia la desligamos de supuestos empíricos que la atan a lo perceptual, ello nos permite acercarnos al sujeto en su multidimensionalidad; la experiencia es como un nudo que incluye los afectos, lo corporal, lo cognitivo en la confección del sentido intersubjetivo, comunitario. Por otro lado, la experiencia ha sido un baluarte que nos ha potenciado la comprensión de las prácticas educativas (LANGFORD, 1994) como actividades abiertas a la incertidumbre, la irrepetibilidad 
y la singularidad. Además, asumimos al sujeto en tanto agente activo (REYNOLDS, 2003) que -en el vínculo con el otro (real o imaginario)da forma al sentido de estar en el mundo.

En quinto lugar, entendemos la noción de experiencia como la trayectoria de una mariposa; como un constante esfuerzo de organización ante las incertidumbres de la vida, como reorganización o negociación de las creencias (memoria, saber, recuerdo); la experiencia está siempre por edificarse. En torno al dispositivo de escritura utilizado, asumimos la idea de trayectorias-biografización: "en la narración biográfica el individuo toma forma, elabora y experimenta su vida... Con ello, el sujeto se interpreta y construye, así se sitúa, une y da significado a los acontecimientos de su vida" (DELORY-MOMBERGER, 2009, pp.57-69). En sexto lugar, asumir esta versión de la experiencia nos posiciona a trabajar en las situaciones prácticas y deliberativas con tacto (VAN MANEN, 2003), con la puesta en juego de cierta ética del respeto al otro; no basta con mostrar la voz de los actores, hay cierta ética en su exposición. Finalmente, la noción de experiencia asumida nos permite mostrar al yo de los participantes en el proceso en sus diferentes posiciones que adquiere el yo en el proceso en la parte formativa de la experiencia del programa Entre Pares. Como vasos comunicantes, los modos en los que el yo se posiciona en el mundo se resaltan en el proceso de documentación de la experiencia; resaltamos el proceso de implicación de los sujetos en las prácticas sociales con ganancias en los modos de ser para participar en la vida social en su conjunto.

El acompañamiento a los estudiantes de primer semestre precisa de la escritura constante del conjunto de participantes. En consecuencia, el diario de reflexión adquiere un lugar central para propiciar deliberaciones diversas: sobre las temáticas del curso, sobre el proceso de acompañamiento, sobre sus trayectorias biográficas y su vínculo con la escritura académica.

\section{Transitar en tiempos de pandemia, la narrativa de los estudiantes}

La emergencia sanitaria, supuso cambios abruptos de diversa magnitud, fue eje central en las emociones, fantasías, anécdotas, pensamientos, sueños, y fantasmas de los estudiantes de primer año. En el marco de la emergencia sanitaria, además, las actividades escolares mudaron del entorno escolar a los espacios virtuales, implicó el desarrollo de actividades académicas en línea, entre ellas, la escritura de textos reflexivos en torno a su hacer en tiempos de Covid-19. Los estudiantes del grupo al que hacemos referencia construyeron, desde que inició la cuarentena hasta finales del semestre (del 23 de marzo al 26 de junio de 2020), un texto individual donde abordaron aspectos como la información acerca de la pandemia, la forma de vida de su familia y familiares cercanos, la convivencia en casa y un día para ellos dentro de la cuarentena, las experiencias dentro de su comunidad y todo aquello que escucharon de sus vecinos o amigos; las tareas y actividades escolares; los pensamientos, emociones y reflexiones a partir de la diversa información científica, política, internacional durante ese lapso de tiempo. El texto lo organizaron con estructuras variadas: algunos a manera de carta, otros, como un diario o una conversación con otro. El trabajo lo enviaban vía correo electrónico cada quince días con un tutor-acompañante asignado del programa Entre Pares, quien les dio retroalimentación sobre el texto en su contenido y estructura. En consecuencia, se formaron fuertes vínculos entre estudiantes de primer año de edu- 
cación superior y estudiantes del último año, pues ambos, ante el complicado momento social, compartieron momentos de reflexión, de escucha y de empatía mutua. Siempre buscaron los medios para intercambiar ideas: videoconferencias, mensajes por Facebook o plataformas como Google Classroom o Whatsapp, correo electrónico y con el seguimiento de actividades en línea que contribuyeran al cumplimiento de los objetivos del curso. Asimismo, dadas las circunstancias de nuestros estudiantes, dentro de las actividades, procuramos documentar cómo se enfrentaban a esta situación $y$, en particular, que reflexionaran sobre la forma en que la pandemia había trastocado sus entornos.

En el periodo escolar (enero-junio), trabajamos con cuarenta y seis estudiantes. En abril, después del inicio de la cuarentena en México, iniciamos ejercicios de recuperación de vivencias en torno a la emergencia sanitaria con temas vinculados al Covid en su vida: la familia, la escuela, la comunidad, fantasías y fantasmas, actividades, entre otros. El ejercicio tuvo acompañamiento tanto de los docentes como de los tutores pares. Cinco estudiantes no realizaron la actividad, una estudiante hizo un relato corto y treinta y ocho estudiantes fueron constantes en la escritura.

Recuperamos trazos de la historia de los coetáneos a partir de las experiencias vividas por los estudiantes en esta situación de emergencia. En el siguiente apartado mostramos sus travesías y reflexiones ante el Covid. Damos cuenta de los variados sentidos que dan de la experiencia de vivir en una época de pandemia en tres categorías: el saber caótico del virus; el Covid en casa y mu/danzas en la vida cotidiana y en las trayectorias formativas. Recuperamos extractos de sus narrativas, utilizamos sus iniciales para identificarlos. En los extractos recuperados respetamos la forma y estilo de escritura de cada uno de ellos.

\section{El saber caótico del virus}

La información del coronavirus llegó al mundo a cuenta gotas. Durante los primeros meses vimos cómo la OMS transformaba su vocabulario. El 31 de diciembre de 2019, China reporta "conglomerado de casos de neumonía" (OMS, 2020) en la ciudad de Wuhan; la nueva infección pasó a ser calificada de epidemia hasta llegar a la declaración de pandemia el 11 de marzo de 2020 cuando se considera que la extensión del problema de salud ha pasado a varios países, incluso continentes. En enero del 2020, el trabajo de organizaciones científicas se acelera; se plantean procedimientos para el encuentro con pacientes con el virus. Hacia el 12 de enero China ya establece una secuencia del virus para que la comunidad científica elabore protocolos.

Mientras tanto, en México, las noticias se difunden en noticieros televisivos, radiofónicos o en periódicos. El Gobierno de México, a través de la Secretaría de Salud, emite un comunicado a partir del recién formado Consejo de Salubridad General. El vocabulario se amplía, "emergencia sanitaria", significante que inicia su circulación en el panorama nacional.

La toma de decisiones no es uniforme en las dependencias del Gobierno de México: el 23 de marzo, la Secretaría de Educación Pública suspende las actividades en el sistema educativo nacional. Por su lado, el Consejo de Salubridad General emite un comunicado de suspensión nacional de actividades del 30 de marzo al 30 de abril. El Gobierno de México inicia con las sesiones vespertinas de informe a la nación sobre el desarrollo de la pandemia en el país. Aparece como rock star (así calificados por algunos) el doctor López-Gatell como vocero. Da a luz el tesoro lingüístico que acompaña a la información. Uno de ellos es "evidencia científica", especialmente rela- 
cionado con el uso del cubrebocas. Políticos y miembros del Consejo de Salubridad General - para algunos sectores de la población- no actuaron como modelaje desde el inicio de las sesiones informativas. El país se cubre de colores, de datos numéricos y se suma la información de diversos países: estrategias de retención en unos, liberación de actividades en otros, unos más sin informar suficientemente a su población. Los tres órdenes de gobierno (federal, estatal y municipalidad) toman decisiones diferenciadas o contradictorias respecto a la contención del virus. A nivel internacional, el primero de mayo, Trump - presidente de Estados Unidos- afirma tener evidencias de que el coronavirus es producto de unos laboratorios en China. En Brasil, Bolsonaro reitera afirmaciones y estrategias del presidente norteamericano. Por diversas latitudes, afloran soluciones de diverso tipo para tratar el virus: naturistas, de usos y costumbres, medicina basada en evidencias científicas. La competencia por la elaboración de la vacuna o de algún procedimiento para contener el virus o tratarlo es tema de todos los días. Hay anuncio de elaboración de vacunas. Este caos se expresa en los documentos elaborados por los estudiantes.

El tema Covid surge en diversos momentos de la convivencia social. Los comentarios expresan el sentido que los individuos le dan a la información. Conjunto de creencias reunidas, procedentes de diversas fuentes que se condensan en expresiones temáticas. En una reunión de vecinos, LJ refiere comentarios sobre el asunto.

Mis vecinos se reunieron para checar la problemática sobre delincuencia de la colonia, pero de pronto salió el tema sobre el virus y se escuchaban sus comentarios --Es una mentira del gobierno para espantarnos--, --no conozco a ningún enfermo ¿y tú?--, --Ojala me de esa madre del virus para toserle a todo el pinche mundo- (LJ, 2020, p. 1)
Se observa que sus vecinos -Alcaldía de Tláhuac, al oriente de la Ciudad de Méxicoestán más preocupados por otra problemática cercana a ellos, la delincuencia, que la del virus. En consecuencia, adoptan una actitud de incredulidad, desaire, arrogancia y falta de interés o empatía hacia lo que sucede en el mundo; hay ganancia en la estructuración del saber construido por las experiencias perceptivas, la inmediatez: no conocen a alguien enfermo.

LJ no se posiciona de manera distinta a la de su comunidad o a la de su familia. Tiene en mente que alguien lo creó o cometió un error de propagación para el mundo. No le teme. Su miedo más profundo radica en la posible necesidad de dejar sus estudios para trabajar y disipar la motivación por asistir a la universidad.

No estoy seguro de qué es ese virus, ni de su procedencia, pero he escuchado tantos comentarios que culpan a los hombres más ricos del mundo para endeudarlo, incluso otras personas aseguran que el virus terminaría con la humanidad, no tengo miedo, al contrario, tengo mucha curiosidad de saber cómo se creó o quien cometió el error de dejar que se propagara, me preocupa más el no ir a la universidad [...] Perdí las ansias de entrar a la escuela, y poco a poco pierdo la motivación que tanto trabajo me costó recuperar. (LJ, 2020, p. 2)

Otra de las estudiantes manifiesta al respecto versiones de cercanos: «He escuchado la idea de que el COVID-19 es mentira y conocidos míos aseguran que se trata del gobierno nos quiere controlar y la vacuna es un "gancho" para ponernos un chip y controlarnos con la señal 5G» (CY, 2020, p. 7).

Por otra parte, hay estudiantes a quienes el tema del virus los ha situado de manera distinta a la mirada de su familia,

Mi madre no cree que el virus sea cierto. Es consciente de la existencia empero no en tal magnitud como lo hacen ver. Ella pensaba en un virus mental provocado por los gobiernos, 
con el propósito de plantar miedo a la sociedad que de por sí ya es débil psicológicamente [...]. En mi punto de vista, el virus sí existe. La forma de vida de muchas personas ha sido interrumpida, nunca más volverá a ser la misma. Lo peor del caso, los medios de comunicación siempre alteran la realidad de los sucesos, su propósito siempre es captar la atención de los receptores para obtener mayores puntajes de influencia (rating). (RE, 2020, p. 5)

RE hace una crítica a lo que observa o escucha en los medios de comunicación. Más adelante, en su trabajo escribe «hay personas que se toman la situación a chiste» (p. 5). Ella lo considera realmente una alerta de salud. Se convirtió en una agente de concientización dentro de su propia familia cuando sus padres quebrantaron su salud: «cuando enfermó mi mamá, regañe a mis padres para que hicieran conciencia del asunto»(RE, 2020, p. 8). Días después, enfermó su papá, quien «llegó con calentura, tos seca y síntomas de gripa. Él fue el primero en preguntarse si estaba contagiado» (p. 9). En consecuencia, la postura inicial de sus padres frente al virus se transformó, tras experimentar los síntomas de contagio.

Hay quienes les molesta, les frustra y emprenden acciones al ver en su comunidad y familia actitudes de desacato de las normas básicas que en México se han estipulado como usar cubrebocas, lavarse las manos frecuentemente, usar gel antibacterial, mantener una distancia de al menos un metro, evitar tocarse los ojos, la nariz y la boca y no realizar reuniones: «al vecino se le ocurrió la grandiosa idea de hacer una fiesta. Los vecinos, por supuesto se enojaron, porque ya no se podía hacer ese tipo de eventos y como era de esperarse, llamaron a la policía para cancelar todo» (GM, 2020, p. 3); «me gustaría que la gente entendiera que no es un juego, es real y es muy peligroso, que hicieran caso y tomen precauciones para que ya no haya tantos contagios y podamos retomar nuestras actividades» (SD, 2020, p. 8).
Frente a otra de las normas que el gobierno mexicano ha señalado con el apoyo de un semáforo: rojo, no salir solo si es estrictamente necesario; o amarillo, quedarse en casa, los estudiantes tienen reflexiones como la siguiente:

En México se dice que nos quedemos en casa, si no tenemos necesidad de salir no lo hagamos, pero en nuestro país existe mucha gente que vive al día, no todos tiene la oportunidad de quedarse en casa y trabajar desde ahí, algunos tienen la oportunidad de quedarse en casa sin goce de sueldo o con muy pocos ingresos que no les ayuda para poder mantener las necesidades de una casa, mucha gente sale día con día para poder comer, a pesar del gran riesgo que corren al salir de casa y poder ser contagiados. (RO, 2020, p. 3)

Así como la anterior, se distinguen distintas posturas, críticas o demandas frente a las acciones del gobierno: «no vi medidas de prevención sanitaria por parte de mi gobierno comparándolo con otros países» (L), 2020, p. 1); «a mi parecer, la negligencia del gobierno mexicano fue lo que provoco que el virus ingresara con tanta facilidad... por permitir la entrada de vuelos de diferentes países» (SA, 2020 , p. 2). Otro alumno añade: «se llegó a rumorar que pondrían sanciones económicas en caso de incumplir con lo estimulado por el gobierno. Algunas patrullas hacían vigilancia o pasaban con altavoces repitiendo "Quédate en casa", "Salva a los tuyos". Nunca vi un cambio»; (RE, 2020, p. 11) o bien:

La respuesta por parte del gobierno no ha sido la que hubiera esperado en casos de una situación como esta. El presidente es visto -por representantes extranjeros-, como una burla y alguien a quien no le importa el pueblo: aconseja salir con familiares y él nos «avisará cuando parar de hacerlo», se respalda de imágenes religiosas y no de información científica y, también, dice que «lo dificil ya pasó». En días recientes la Organización Mundial de la Salud (OMS), pidió al gobierno mexicano tener coherencia, en vista de que el presidente 
dice una cosa y el Subsecretario de Salud, el Dr. López-Gatell, dice que estamos en el punto más crítico de la pandemia. (ZK, 2020, p. 8)

Gran parte de los estudiantes considera que, se pudieron tomar decisiones diferentes desde el inicio, principiando por el líder de la nación, el presidente Andrés Manuel López Obrador; por ejemplo, CY lo manifiesta así:

En el momento que llego el COVID-19 a nuestro país. No lo tomo enserio el gobierno, o al menos eso pareció, mejor las universidades decidieron suspender las actividades que la SEP, cosa que no se me hizo correcta. La población infantil también está en riesgo. Fue por la presión de la ciudadanía que se suspendieran las clases antes y se empezara la cuarentena [...]. Además, que el presidente de la Republica seguía con sus visitas a los estados y en un principio dijo que no dejaran de abrazarse y besarse. Fue el primero en no tomar enserio las indicaciones y hacer comentarios como que está protegido por sus imágenes religiosas.

Como se nota, los estudiantes narran las ideas disímiles que existen sobre el Coronavirus. Hay familias completas que no acatan las normas por no creer, por pensar que es un invento del gobierno o de alguien que «se le escapó de las manos»; hay jóvenes que se han dado la oportunidad de indagar, de dudar, de cuestionar lo que escuchan y toman un posicionamiento frente a la situación de la pandemia; otros tantos, sienten impotencia, frustración y molestia al ser testigos de lo que los otros hacen sin cuidarse y cuidar a la sociedad en general. Aquellos que narraron sobre las acciones del gobierno, coinciden en que las autoridades correspondientes no han actuado con coherencia, responsabilidad o seriedad en el tiempo oportuno frente a la situación que a todos aqueja. Lamentablemente, varios estudiantes han convivido con el Covid de manera cercana. ¿Cómo ha sido su experiencia? En el siguiente apartado, lo desarrollaremos.

\section{El Covid en casa}

El Covid ha pasado a formar parte de nuestro entorno cercano. Nos mantiene confinados, con precauciones de contacto con otros. A pesar de las medidas de seguridad que tomemos nos llegan noticias de personas famosas, compañeros, conocidos, amistades, incluso seres queridos han sido tocados por él. La cantidad de infectados aumenta día con día. Junto con el conteo de los infectados, los recuperados, las camas disponibles, aparece el número de fallecimientos. La muerte se volvió parte de nuestro día a día. Como la décima plaga que azotó al pueblo de Israel, cerca de casa nos hemos topado con la muerte de seres queridos. Con frecuencia, recibimos la noticia del fallecimiento de una persona conocida. Los relatos de los estudiantes dan cuenta de ello.

En sus narrativas, dieciocho de los treinta y ocho escritos de estudiantes de primer año de licenciatura hacen alusión a muerte por Covid de familiares, amigos o personas cercanas. El nuevo virus ha tocado la vida del cuarenta y siete por ciento de los alumnos. En este contexto, los sujetos nos enfrentamos a un vaivén de emociones, ligadas con los protocolos de seguridad que hay que seguir, la dificultad para reconocer a nuestros familiares o, incluso, llevar a cabo rituales de despedida (velorios, reuniones familiares, sepelios).

Conmoción, sorpresa, contrariedad, tristeza, enojo, impotencia, desolación son algunas de las emociones que conlleva la despedida de un ser querido en tiempos de Covid; aunado a la preocupación por familiares aún enfermos de los que no podemos estar cerca. La muerte se vive de forma transmutada, en palabras de los estudiantes:

Así como desperté, recibí la mala noticia de que la señora Ceno [tía de su suegra] se puso grave. La llevaban camino al hospital, sin embargo, ya no resistió. Se quedó dormida, no despertó. Todos estamos muy conmovidos. Es horrible no 
poder acompañar a la familia en un momento tan dificil. Es increíble saber que se te fue un ser querido a causa de esta enfermedad. Me hizo tomar conciencia de tener todas las medidas necesarias. Temo que le pase algo a mi hijo. (AC, 2020, p. 14)

Otra de las estudiantes menciona: «desafortunadamente falleció una tía. Fue algo que no esperábamos y más triste fue porque no pudimos ir a despedirnos por la situación de [Quédate en casa]»(CZ, 2020, p. 5). Además, del dolor que ocasiona no acompañar a los seres queridos durante el inicio del duelo, hay quienes han perdido a más de un familiar en la misma semana y dan cuenta de los cuidados desatendidos por negligencia:

La salud de mi tío empeoró durante su estancia en el hospital. Finalmente, el lunes 23 de marzo falleció sin poder despedirse de algún familiar (pensar en cómo fueron los últimos momentos de vida de mi tío resulta doloroso para la familia).

Cabe destacar que en el hospital hubo otro caso de Covid-19, al cual trasladaron a La Raza. Sin embargo, médicos y enfermeras tampoco llevaron a cabo el protocolo de cuidados, pues ningún directivo les informó del caso. Mi prima María Teresa falleció 4 días después del deceso de su padre. Los médicos a cargo indicaron que la causa de su muerte fue por un cuadro de neumonía aguda, causada por el COVID-19. (HH, 2020, p. 4)

Los aditamentos que actualmente se utilizan tanto antes como después de la muerte son algo que también ha transformado la vivencia de la muerte, «me resultó impactante ver esta escena en la calle, ver el traje que utilizan los camilleros y la camilla totalmente cubierta de una especie de plástico transparente para sacar a mi vecino fallecido por Covid» (SM, 2020, p. 7).

Una de las cuestiones que también impacta de este virus entre los jóvenes estudiantes es que le puede afectar tanto a una persona mayor como a un coetáneo:
El caso más impactante para mí fue que a un señor, su jefe, se le murieron sus tres hijos mayores a causa de este virus y su hija estaba internada, fue algo que nos impresiono, dice ella que los muchachos no eran grandes y se veían ser saludables. (CY, 2020, p. 7)

Un alumno describe vivir con «horror» la muerte cercana de un vecino solitario, a quien encontraron después de dos días de muerto. Personal del gobierno llegó para desinfectar todo el edificio y pedirles a los inquilinos que no salieran por quince días: «el terror se respiraba, nadie quería pasar por esa sección, de hecho, la misma familia del fallecido tuvieron que hacer carteles de denuncia pues los vecinos los discriminaban por el fallecimiento de su familiar, llamándolos “ignorantes”» (MJ, 2020, p. 4).

En cualquier momento las noticias sobre un familiar, amigo o conocido fallecido han llegado a sus oídos. Viven con aprensión. Si bien, el virus se complica en una persona sana, lo hace con mayor posibilidad en personas con otro tipo de enfermedades. La ilusión de que se encuentren en «un mejor lugar» sin más sufrimiento, se hace presente:

Fue una madrugada cuando sonó el teléfono de mi papá, era una llamada de mi prima Elizabeth; nos dijo que había fallecido mi tía Andrea y su esposo, ellos llevaban días en el hospital en una situación delicada, Andrea tenía diabetes e hipertensión y su esposo era diabético. Ahora ellos están en un mejor lugar, pero nos dejaron un vacío en el corazón a todos. (CK, 2020, p. 3)

La cantidad de personas conocidas para los estudiantes que han fallecido ha sido amplia, «a mediados de Abril y principios de Mayo empezaron a fallecer personas que vivían cerca de mi callejón, mi familia empezó a tener miedo porque fueron más de 80 personas de la misma calle» (CZ, 2020, p. 3). Otro de los estudiantes relata: «respecto a los contagios en mi colonia, hemos tenido 3 fallecidos, 2 de la 
misma casa y otro que solía vender materias primas» (EE, 2020, p.2). Así mismo, «en estos últimos días han fallecido 2 vecinos de $\mathrm{mi}$ calle a causa del covid, la gente de mi calle tiene miedo de salir, cada vez se ven más casos de contagiados en nuestro alrededor» $(\mathrm{RO}, 2020$, p. 4).

Hay un fantasma persistente que surge frente a la enfermedad, si una persona ingresa al hospital enfermo, no sale de ahí más que muerto: «la amiga de mi mamá por el momento necesita un respirador, no quiso ir a un hospital. Dice que de ahí sale muerta, por lo que prefirió resguardarse en casa y ahí tomar sus medicamentos» (GD, 2020, p. 6); «hoy 23 de junio un vecino, papá de una compañera de la primaria falleció por Covid-19, el señor no quiso ir al hospital dijo que solo le consiguieran tanques de oxígeno, pero la familia no pudo conseguirlos, eso ocasiono la muerte del señor» (SD, 2020, p. 8). Finalmente, otro de los alumnos refiere,

Fue algo dificil y raro para toda su familia [del amigo de su papá], un día antes se encontraba muy bien y listo para salir del hospital y de la nada fueron informados de su fallecimiento. Su esposa sólo iría a reconocer el cuerpo y posteriormente se le entregaron las cenizas. (RO, 2020 , p. 2)

A pesar de las circunstancias narradas, la esperanza también es un elemento importante expresado en las narraciones de los jóvenes estudiantes. Si alguien se contagia, también se puede recuperar:

Nos dijeron que mi tía Paula -hermana de mi mamá-, salió positiva en la prueba del Covid-19; eso no fue todo, su esposo nos lo conto hasta que mi tía estaba llegando a fase terminal -ya no nos daban esperanzas de vida para ella-, esta noticia devastó principalmente a mi abuela. Se tuvo que comprar oxígeno, se aisló totalmente de su familia, se rento una maquina especial para que ayudara a sus pulmones a mejorar un poco, fueron días dificiles, pero con el paso del tiempo ella fue mejorando y hasta la fecha ella se encuentra bien. (CK, 2020, p. 3)

En la misma línea, personas que necesitan salir a trabajar, que han enfermado, pero se han recuperado, encontramos:

Uno de mis tíos, hermano de mi papá, vive en Tlapacoya, Estado de México, trabaja en el transporte público, depende de lo que gane para poder llevar algo de comer a su casa, porque el transporte no es muy usado en estos días. A pesar de que tomo medidas de precaución salió positivo en la prueba. Estuvo un mes encerrado, no salía, le mandaron medicamentos y se recuperó, ya se encuentra mejor, aún con medicamentos para que no decaiga. (SD, 2020, p. 8)

En resumen, la muerte ha estado presente en la vida de los jóvenes estudiantes a través de sus amigos, familiares, vecinos u otras personas cercanas en un corto lapso, con un número significativo de personas a la vez y de diversas edades. Lo que más lamentan es no estar presentes para acompañar en la despedida a sus conocidos. Les sorprenden las modificaciones que han tenido las despedidas: con aditamentos, sin últimas palabras o visitas $y$, necesariamente, con cremación. Lo que han escuchado de personas cercanas es la idea de no ir al hospital cuando se contagian del virus, para evitar la muerte. A pesar de las circunstancias complicadas, se denotan dejos de esperanza en las historias de las personas que se recuperan, que logran salir después de la enfermedad.

\section{Mu/danzas en la vida cotidiana y en las trayectorias formativas}

Vivir la pandemia ha significado experimentar de manera disímil la cotidianeidad a la que estábamos acostumbrados. El gobierno mexicano solicitó a la población quedarse en casa, como prevención principal para la propaga- 
ción del virus. Los estudiantes por vez primera han cohabitado continuamente con su familia, lo que ha generado modificaciones en su convivencia, en su estado de ánimo, en su manera de relacionarse consigo mismos y con los otros. En consecuencia, lo anterior ha afectado también en su desempeño y formación académica; por no contar con el tiempo y espacio necesarios para atender los asuntos escolares; por no adaptarse y comprender la forma de ponerse al tanto en las actividades a distancia; o bien, por la necesidad de elegir entre apoyar en lo económico o continuar con su educación universitaria.

En los relatos de los estudiantes se distinguen familias con diversas posiciones laborales -y por tanto económicas-. Aquellos que pueden trabajar en casa y recibir su sueldo sin modificaciones, "en mi familia "afortunadamente" no nos ha pegado tan duro el lado de la economía, como somos empleados de gobierno tenemos la garantía de recibir nuestra quincena a pesar de que nos descansaron a mi madre y a mí» (CY, 2020, p. 4). Otros se han quedado sin empleo. Unos más -que no son pocos- deben continuar laborando: «mi mamá es enfermera del hospital Darío Fernández Fierro, está ubicado en Barranca del Muerto, que fue declarado hospital dedicado para atender casos de covid-19. Cuando mi mamá me dio esa notica me quedé impactado, mi propia madre está expuesta» (DE, 2020, p. 2). En cada situación, la convivencia y el desempeño académico, por ende, es desemejante.

Para aquellos que conviven diariamente en casa con su familia relatan experiencias que han gozado con los suyos -y que hasta expresan como lo positivo de la pandemia- como explorar fotografías de años atrás y crear álbumes (CZ, 2020, p. 5); visitar museos en línea, ver series en Netflix o conocer juegos de mesa (ZK, 2020, p.4); realizar quehacer 'extremo' (limpiar y acomodar), practicar ejercicio o tomar clases en línea de diversas temáticas (SA, 2020, p. 3); festejar por Zoom el Día del Niño, Día de las Madres, el Día del Padre o cumpleaños; desayunar, comer y cenar en familia (AC, 2020, p. 6) o hacer videos en la aplicación 'de moda' TikTok (ArC, 2020, p. 13).

Al transcurrir de las semanas, los días se han vuelto rutinarios «despertar desayunar, hacer tareas... comer, cenar, etc» (ArC, 2020, p. 4), lo que conlleva a situaciones como la de $\mathrm{CY}$ :

Conforme avanza el confinamiento se ha vuelto pesada la convivencia entre nosotros, ya estamos algo fastidiados del encierro, los primeros dos meses fueron tranquilos, pero con el tiempo salir solo al mandado es pesado. De igual modo no estamos acostumbrados a pasar tanto tiempo en la casa juntos, es un tanto desesperante, pues no coincidimos en nuestras formas de pensar, ni de ser, trato de evitar algún rose con ellos, pero es complicado. (CY, 2020, p. 5)

Algo parecido ha sucedido con ArC, «mi relación con él [su esposo] va un poco mal. La cuarentena nos pone es situaciones complicadas. He discutido mucho. No estamos acostumbrados a pasar mucho tiempo juntos. Nuestros ideales chocan. Es dificil estar bien todo el tiempo» (2020, p. 5). La cuarentena ha significado una etapa para tomar la decisión de buscar ayuda terapéutica como pareja:

Decidimos buscar ayuda. Fuimos a un lugar en donde están dispuestos a darnos terapia de pareja. No creemos que la separación sea una opción. 0 al menos, no hasta que hayamos hecho hasta lo imposible por tener una buena relación de padres como de pareja, una relación sana. Si llegamos a separarnos sea para bien de los tres. (ArC, 2020, p. 15)

Sobre la misma línea, en el texto de GM se denota desesperación, desorientación de cómo afrontar los días en casa:

Suplicamos fuerzas para aguantar el hecho de estar encerradas. Los primeros días recuerdo me la pasaba durmiendo, soló comía, dormía y le ayudaba de repente a mi madre cuando me 
lo pedía. Llegó un momento, donde eso ya no me gusto, sentía que comenzaba a deprimirme y me propuse arreglar mi cuarto, comencé a hacer ejercicio, subía a la azotea para asolearme un rato, de vez en cuando, me ponía a leer y realizar mis tareas. (GM, 2020, p. 3)

Tiene una imagen sobre sí misma de no estar aprovechando su tiempo, de estar «desperdiciando mis días» (GM, 2020, p. 4). En el caso de FE, sabe que lo que acontece es algo histórico y decide escribir una carta para el futuro a su hermanito quien actualmente tiene dos años. Le cuenta las pericias del día a día, ya como si todo hubiese quedado atrás:

En la casa, nos comenzábamos a estresar por el encierro y porque estábamos juntos. En ocasiones fue agobiante, como cuando Alma se enojaba o mi papá estaba estresado por el trabajo; imagínate: jestresados y juntos! Tú también provocabas peleas a tu corta edad porque hacías travesuras y berrinches porque no te dejábamos hacer lo que quieras como, por ejemplo, mojarte o salir a la calle. Mis papás se enojaban y desesperaban. (FE, 2020, p. 2)

Pese a todo lo anterior, los estudiantes intentan continuar con su formación académica. La montaña rusa de emociones ha sido parte del día a día: «la cuarentena está afectada un poco mi salud emocional, estoy muy inestable, a veces estoy ansioso, de la nada me pongo triste con ganas de llorar, de repente me pongo feliz con ganas de reír a carcajadas, me cuesta concentrarme» (DE, 2020, p. 3); «este encierro me estresa mucho últimamente. Quisiera volver a la universidad. Pienso que no estoy aprendiendo como debería, me cuesta trabajo adaptarme» (ArC, 2020, p. 10). Por otro lado, RE señala: "Todo me tenía estresada, me quede sin ganas, ideas en mí y un tanto cansada, lo que me trajo problemas en una asignatura» (RE, 2020, p. 9).

Para algunos ha sido más sencillo que para otros: cuentan con las condiciones necesarias. En cambio, para una buena parte de los estu- diantes, la condición actual los lleva a hacer diversas elecciones: horarios para el uso de la única computadora en casa, búsqueda de sitios con internet para trabajar o descargar las actividades en línea, poner atención a su rol como padres de familia, esposos o estudiantes en el mismo espacio o ayudar a su familia en la parte económica en vez de continuar con su formación.

Con relación a los usos de la computadora, GM comenta:

Mi mamá, mi hermana y yo, apartamos la computadora entre nosotras para hacer nuestras actividades y tareas; por ejemplo, yo pido dos turnos por las dos carreras que estudio «Administración Educativa en la UPN y Economía en la UNAM», porque han comenzado a dejar bastantes trabajos y aunque casi siempre me toca en la noche también apartó en la mañana y así aprovecho mi tiempo para terminar todo. (GM, 2020, p. 2)

En el caso de LJ, debe salir de casa para realizar sus actividades escolares en un "Café-Internet": «solo había 5 computadoras en el internet y las 5 estaban ocupadas, algo preocupado debido a que tengo tarea de todas mis materias» (LJ, 2020, p. 4). Para MJ, contar con la contraseña del Wifi que le pasó su vecino es una fortuna «y gracias a ello he podido completar algunas tareas que tenía» (MJ, 2020, p. 3).

Aquellos estudiantes que son padres de familia expresan sentirse estresados e incapaces de llevar a cabo todas las tareas y actividades de sus diversos roles, «algunos profesores nos saturan de tarea, a veces siento que me vuelvo loca. Hay cosas que hacer por todos lados, pienso que es el precio de tener un hijo a temprana edad» (ArC, 2020, p. 14). Otro estudiante, advierte sobre el asunto: "realizar mis actividades escolares es dificil porque debo supervisar a mis niños con sus tareas o que simplemente quieran estar un momento conmigo. Regularmente mi mamá me apoya, pero ahora no cree que estemos con trabajos» (CY, 2020, 
p. 3). En esta misma línea de pensamiento SM afirma que «el día de hoy siento que ya no puedo entre las labores de la casa, tareas de la universidad, la responsabilidad total de mis hijos... siento que voy a terminar loca... siento que la situación me sobrepasa»; (SM, 2020, p. 4). A otros alumnos la situación de las medidas sanitarias los desorienta: «a veces me pongo sentimental y me dan ganas de llorar, siento que ser mamá y la universidad me ha quedado grande; me siento desubicada, triste y estoy de mal humor todo el tiempo» (SM, 2020, p. 8).

La economía, sin duda, fue un factor trascendente para el desempeño académico de algunos alumnos, para algunos la salvación de trabajar pasa por los apoyos que reciben del gobierno:

Solicite trabajo mediante aplicación de Indeed, bolsa de trabajo y saliendo a repartir solicitudes con la esperanza de que alguna me llame, pues mi situación será incontrolable si dejo pasar mas tiempo. Otra vez la Beca académica me salvo un mes de renta (LJ, 2020, p. 6)

Conseguir trabajo fue una prioridad, «no recuerdo muy bien, cuando empezaron a enviar las tareas que debíamos hacer, para continuar con nuestro semestre. estaba más preocupado por encontrar un trabajo para sacar algo de dinero y poder pagar mis deudas» (MJ, 2020, p. 2). Por el mismo motivo, hubo estudiantes que no enviaron ni tareas ni actividades, como es el caso de $\mathrm{MaC}$, quien informó por correo electrónico lo siguiente:

Mi familia y yo pasamos por tiempos complicados económicamente por lo que he descuidado todas mis materias, todos salimos a trabajar todos los días y me es imposible ir a un ciber a realizar mis trabajos [...] la pandemia nos afecto en lo económico más que en la salud. (MaC, 2020)

Además, hay una percepción general de trabajar más con las actividades y tareas enviadas por medios electrónicos que cuando asisten presencialmente a clases, «creo que nos dejan el doble de trabajo que cuando asistíamos a la universidad» (ArC, 2020, p. 16); «este día se me fue haciendo tarea. Solo hice pausa para comer» (SM, 2020, p.15); «los profesores nos han dado fecha para entregar proyectos que se han trabajado durante el semestre, en muchas ocasiones me desvelo $y$, aun así, me falta tiempo para acabar los trabajos» (GL, 2020, p. 5).

Así mismo, los estudiantes expresan de qué manera han padecido el no ir a clases presenciales. Una minoría tenía ya la experiencia de estudiar a distancia, lo que les ayudó a desenvolverse sin problema en esta etapa de emergencia:

No se me ha hecho dificil estudiar desde mi casa. Estudié la preparatoria en sistema abierto en el Estado de México. Fueron más de tres años de estudio desde casa; todo esto me ayudó a desarrollar disciplina, aprendí a tener un horario para mis clases y a buscar la información por mí misma para entender mejor las materias. (AC, 2020, p. 4)

Empero, la mayoría siente que la transición ha sido ardua «el aprendizaje a distancia es algo complejo. Me cuesta trabajo entender algunas cosas estando, en la clase, solo por un mensaje con indicaciones es bastante complicada». (CY, 2020, p.3). La misma estudiante, dentro de su texto, más adelante expresa:

La experiencia de la educación a distancia es compleja en todos los aspectos, el hecho de que las indicaciones sean solo por e-mail y no tener la retroalimentación de parte de los profesores, la comunicación con los compañeros es escasa y eso complica realizar los trabajos en equipo (esa parte de los equipos fue lo que más trabajo me costó, no hay una buena comunicación con los compañeros, además las excusas y justificaciones para no trabajar, hacer poco o no aportar nada a los trabajos fue algo constante), las fallas del internet y de mi equipo de cómputo, entre otras cuestiones son de las cosas que no me agradan de esta forma de trabajo. (CY, 2020, p. 8) 
A través de las dificultades que los jóvenes han vivenciado en esta pandemia, se ha transformado su mirada, han valorado lo esencial en sus vidas y lo que desean para su futuro; así lo expresan: «hoy desperté sintiéndome muy agradecida... estamos viviendo una situación muy dificil, pero no nos falta nada a mi familia y a mí... [la situación de la pandemia] me hace pensar en que tengo que echarle ganas a la vida, a la universidad» (AC, 2020, p. 7).

\section{A manera de conclusión}

Lo que la pandemia vino a demostrar es la falta de un continente en el cual sustentar el largo vínculo de la humanidad y sus pandemias. Según muestra la documentación de las pandemias, con el tiempo, todas han tenido efectos en el espacio social: psicológicos, sociales, culturales, económicos, urbanos, legales, arquitectónicos. Derivaciones, incluso en la configuración del saber disciplinario en las ciencias sociales. Sin dejar de vislumbrarse efectos en el campo del cuidado de sí y de los otros. Ahora también en las prácticas educativas en contextos institucionales. La pandemia ha desnudado varios problemas sociales: la desigualdad económica, la visión educativa, los fantasmas y fantasías a consecuencia de la cuarentena; la distancia entre propuestas del gobierno y las esperadas por la población. No obstante, también ha generado esperanza, reflexiones sobre las acciones pasadas y las metas a futuro, sobre el sentido de la vida.

La emergencia sanitaria se convirtió en el tema central de las conversaciones, es un acontecimiento que trastocó las vidas de nuestros estudiantes. Se convirtieron en testigos de la historia y sus escritos en la memoria, en el testimonio de tal acontecimiento. Sus narrativas ponen sobre la mesa no solo las mu/ danzas vividas, también tareas pendientes de los gobiernos y de la sociedad en su conjunto.
Quedaron de manifiesto las debilidades de los gobiernos en los campos de educación, salud, seguridad. Así mismo, desvelan los efectos que tiene una pandemia en las relaciones sociales, desde el alejamiento de los pares, aislamiento de los amigos, apartamiento de los familiares en momentos importantes (la pérdida de un ser querido) hasta las tensiones, necesidades que surgen por la convivencia constante en entornos familiares.

La irrupción del coronavirus muestra la amplitud de lo que es la humanidad. Desde la indiferencia y la ignorancia -que profundiza el problema-, hasta la solidaridad más viva de apoyo al otro, en el paso hay no pocas variaciones sobre la atención al problema. En materia educativa, los diseñadores de planes de estudio no estuvieron a la altura para mostrar contenidos, estrategias o por lo menos saber enciclopédico sobre las historias de las pandemias y sus consecuencias. Hay un abismo de más de 100 años en nuestra formación como sujetos escolarizados-ciudadanos.

Por otro lado, la sociedad tiene dos frentes, combatir la pandemia de la enfermedad y la epidemia del escepticismo y la desinformación. Sorprende la cantidad de información que circula con el firme propósito de desinformar y de alterar a la población. Sorprenden las reticencias a usar algunas medidas que han sido efectivas en otros países, con el supuesto de que no tienen evidencias científicas. Sorprende la propuesta de medidas por las autoridades sanitarias o políticas sin que ellos se las apliquen a sí mismos.

El futuro será siempre incierto. No sabemos qué acontecerá en materia educativa, solo sabemos que los próximos meses recurriremos a estrategias y formas de vida y trabajo a la que no estábamos acostumbrados ni los alumnos ni los profesores ni los administrativos. Al paso habrá que crear nuevas formas de relación con los otros para sostener nuestras maneras rea- 
les o imaginarias de afrontar la vida en confinamiento. En nuestro país, los sismos y los huracanes nos han llevado a estar confinados, de ello hemos aprendido. Estaremos a la espera de encontrar nuevas vías de reconstitución de las relaciones sociales.

Como sociedad, precisamos conocer narraciones individuales/grupales de la vivencia de la pandemia; nunca serán pocos los textos que nos muestren las maneras de enfrentar la experiencia humana en épocas de pandemia. Con el tiempo serán la fuente de trabajo de los historiadores, de los educadores para escribir de nuestro tiempo. Como ciudadanos de esta época, precisamos organizar nuestro saber. Sor Juana Inés de la Cruz, quien -al cuidar a sus hermanas enfermas- también murió en época de pandemia en México escribió "Yo no estudio para escribir, ni menos para enseñar (que fuera en mi desmedida soberbia), sino sólo para ver si con estudiar ignoro menos". Ignorar menos para proyectar vida con sentido colaborativo, pues el otro importa. Vaya nuestro reconocimiento a los que luchan y amplian el saber que nos permitirá sobrevivir, y un abrazo amplio a los que han perdido seres queridos en tan dificiles momentos.

\section{Referencias bibliográficas}

AGAMBEN, Giorgio. Homo sacer. El poder soberano y la nuda vida. Valencia: Pre-textos, 1995.

ARÓSTEGUI, Julio. La historia vivida. Sobre la historia del presente. Madrid: Alianza Editorial, 2004.

BOLIVAR, Antonio; DOMINGO, Jesús. La investigación (auto)biográfica en educación. Barcelona: Octaedro, 2019.

BOURDIEU, Pierre. Razones prácticas. Sobre la teoría de la acción. Barcelona: Anagrama, 1997.

BRUNER, Jerome. La fábrica de hacer historias. Derecho, literatura, vida. Ciudad de México: Fondo de Cultura Económica, 2002.
CONNELLY, Michael; CLANDININ, Jean. Relatos de experiencia e investigación narrativa. En: LARROSA, Jorge et. alli. Déjame que te cuente: Ensayos sobre narrativa y educación. Barcelona: Laertes, 1995. p. 11-59.

CONTRERAS, José; PÉREZ DE LARA, Nuria. Investigar la experiencia educativa. Madrid: Morata, 2010.

DEBRAY, Régis. Transmitir. Buenos Aires: Manantial, 1997.

DE (Diccionario etimológico) (s/f). Recordar. Disponível em http://etimologias.dechile.net/?recordar. Acesso em 30 jun. 2020.

DELACROIX, Christian. L'histoire du temps présent, une histoire (vraiment) comme les autres ? Tempo e Argumento, Florianópolis, v. 10, n. 23, p. 05 - 38, jan./mar. 2018. DOI: 10.5965/2175180310232018005. Disponivel em https://www.revistas.udesc.br/index.php/tempo/article/view/2175180310232018005. Acesso em 21 abr. 2020.

DE LA IGLESIA, Jesús. Las artes liberales en la Biblioteca Real del Escorial, dos antecedentes iconográficos. Disponivel em file:///C:/Users/MyPC/Downloads/Dialnet-, (s/f). LasArtesLiberalesEnLaBibliotecaRealDelEscorial-2855778\%20(1).pdf. Acesso em 26 jul. 2020.

DELORY-MOMBERGER, Christine. Biografia y educación. Figuras del individuo-proyecto. Buenos Aires: FFyL-UBA-FLACSO, 2009.

DEWEY, John. El arte como experiencia. Barcelona: Paidós, 2008.

DUBY, Georges. El año mil. Gedisa: Ciudad de México, 1989.

EISNER, Elliot. El ojo ilustrado. Indagación cualitativa y mejora de la práctica educativa. Barcelona: Paidós, 1998.

FUENTES, Nara Victoria. El lugar de producción de la Historia: el sujeto histórico Michel de Certeau. Anuario Colombiano de Historia Social y de la Cultura, núm, 34, pp. 475-497. Universidad Nacional de Colombia Bogotá. Disponível em https://www.redalyc.org/articulo.oa?id=127112570013, 2007. Acesso 
em 26 jul. 2020.

GRONDIN, Jean. A la escucha del sentido. Conversaciones con Marc-Antoine Vallée. Barcelona: Herder, 2014.

DIETZ, Gunther; MATEOS, Laura Selene. La interculturalidad educativa en tiempos de pandemia Muchas sombras y algunas luces. En CLACSO. Boletin del Grupo de Trabajo Educación e interculturalidad. Disponivel em https://www.clacso.org/wp-content/uploads/2020/07/V2_Educar-en-la-diversidad_N1.pdf, 2020. Acesso em 26 jul. 2020.

HARARI, Yuval Noah. Na batalha contra o coronavírus, faltam líderes à humanidade. Companhia das letras. 2020. Disponível em https:/ / play.google. $\mathrm{com} /$ books/reader?id=vVbZDwAAQBAJ\&hl=es\&pg=GBS.PP1, Acesso em 26 jul. 2020.

HERNÁNDEZ-ZAMORA, Gregorio. Cultura escrita en espacios no escolares. En: CARRASCO, Alma y LÓPEZ-BONILLA, Guadalupe (Coords.). Lenguaje y educación. Temas de investigación educativa en México, serie: lenguaje, educación e innovación (LEI). Libros digitales de acceso libre. Ciudad de México: Fundación SM, 2014. p. 241-286. Disponível em http://ideamex.com.mx/sites/default/files/pdf/ lenguaje_educacion.pdf. Acesso em 22 maio 2020.

HUREMOVIC, Damir. Brief History of Pandemics (Pandemics Throughout History). En HUREMOVIC, Damir. (Ed.). Psychiatry of Pandemics. A mental Health Response to Infection Outbreak, p. 7-35. Switzerland: Springer, 2019a. Disponível em https://www. ncbi.nlm.nih.gov/pmc/articles/PMC7123574/. Acesso em 20 maio 2020.

HUREMOVIC, Damir. Social distancing, Quarantine, and Isolation. En HUREMOVIC, Damir. (Ed.). Psychiatry of Pandemics. A mental Health Response to Infection Outbreak, Switzerland: Springer, 2019a. p. 85-94. Disponível em https://www.springer.com/ gp/book/9783030153458. Acessado em 20/05/2020.

HUSSERL, Edmund. La idea de la fenomenología. Cinco lecciones. México: Fondo de Cultura Económica, 1989.

LANGFORD, Glenn. La enseñanza y la idea de práctica social. En CARR, Wilfred. Calidad de la enseñanza e investigación-acción. Sevilla: Diada Editora, 1994. p. $25-85$.

OMS. COVID-19. Una cronología de la actuación de la OMS. Disponivel em https://www.who.int/es/newsroom/detail/27-04-2020-who-timeline---covid-19. Acesso em 26 jul. 2020.

PASSEGGI, Maria da Conceição. Enfoques narrativos en la investigación educativa brasileña. Revista Paradigma (Edición Cuadragésimo Aniversario: 19802020), Vol. XLI, p. 57-79, 2020.Disponível em http:/ / revistaparadigma.online/ojs/index.php/paradigma/article/view/929. Acesso em 26 jul. 2020.

RAMAZZINI, Bernardino. De Morbis Artificum Diatriba. Tratado sobre las enfermedades de los trabajadores. Madrid: Instituto Nacional de Seguridad e Higiene en el Trabajo-Asociación Instituto Técnico de Prevención, 1743/2011. Disponível em http:/ / www.scielo.org.mx/scielo.php?script=sci_arttext\&pid=S0036-36342002000400010. Acessado em 24/04/2020.

REYNOLDS, Larry. Intellectual Precursors. En: REYNOLDS, Larry; HERMAN-KINNEY, Nancy. Handbook of Symbolic Interactionism. California: Altamira, 2003. p. 39-58.

REEVES, Hubert; DE ROSNAY, Joël; COPPENS, Yves; SIMONNET, Dominique. La más bella historia del mundo. Barcelona: Andrés Bello, 1998.

SERRANO, José Antonio; RAMOS, Juan Mario; BALLESTEROS, Arturo; TRUJILLO, Blanca Flor. Lo biográfico, pases de estafeta y diálogo inter (intra)disciplinario: experiencia y narratividad. Inter-Legere. Revista do Programa de Pós-Graduação em Ciências Socias da UFRN, Natal, n. 16, p. 140-160, jan./jun. 2015. Disponível em https://periodicos.ufrn.br/interlegere/ article/view/8973/6387. Acesso em 26 jul. 2020.

SOUZA, Elizeu Clementino; SERRANO, José Antonio; RAMOS, Juan Mario Autobiografia y educación. Tradiciones, diálogos y metodologías. Revista Mexicana de Investigación Educativa, Ciudad de México, 62.3, p. 683-694. 2014. Disponivel em https://www. redalyc.org/pdf/140/14031461002.pdf. Acesso em 26 maio 2020.

SUÁREZ, Daniel. Docentes, narrativa e investiga- 
ción educativa. La documentación narrativa de las prácticas docentes y la indagación pedagógica del mundo y las experiencias escolares. En SVERDLICK, Ingrid (Comp.). La investigación educativa. Una herramienta de conocimiento y de acción. Buenos Aires: Noveduc, 2007. p. 71-110.

VAN MANEN, Max. Investigación educativa y experiencia vivida. Ciencia humana para una pedagogía de la acción y sensibilidad. Barcelona: Idea Books, 2003.

WENGER, Étienne. Comunidades de práctica. Aprendizaje, significado e identidad. Barcelona: Paidós, 2001.

Recebido em: 07/08/2020

Aprovado em: $14 / 12 / 2020$

José Antonio Serrano Castañeda es Doctor en Pedagogía por la Universidad de Barcelona. Profesor Titular, SNI-1 Conacyt y profesor PRODEP. Integrante del cuerpo académico consolidado Prácticas institucionales y constitución del sujeto de la educación (CAC PICSE). Es responsable del grupo de investigación dedicado a la reflexión sobre lo biográfico y la narrativa en educación SPECE (Sujetos y prácticas educativas en contextos escolares). Es responsable de la Maestría en Desarrollo Educativo, programa consolidado en las políticas de CONACYT Miembro del SNI-Conacyt, líneas de investigación: curriculum, formación docente, investigación narrativa, literacidad académica. E-mail: jserrano@g.upn.mx

Lorena del Socorro Chavira Álvarez es Maestra en Desarrollo Educativo en la Línea de Prácticas Institucionales y Formación Docente por la Universidad Pedagógica Nacional. Estudiante del Doctorado en Educación de la Universidad Pedagógica Nacional. Líneas de investigación: metodologías globalizadas, investigación narrativa, prácticas de literacidad académica. Secretaría técnica programa Entre Pares y profesora en la Licenciatura en Administración Educativa. E-mail: Ichavira@g.upn.mx

Juan Mario Ramos Morales es Doctor en Ciencias Administrativas por el Instituto Tecnológico y de Estudios Superiores de Monterrey, Campus Ciudad de México. Profesor Titular, SNI-1 Conacyt y profesor PRODEP. Integrante del cuerpo académico consolidado Prácticas institucionales y constitución del sujeto de la educación (CAC PICSE) y de la Red SPECE (Sujetos y prácticas educativas en contextos escolares). Miembro del SNI-Conacyt, líneas de investigación: prácticas profesionales, prácticas de formación, prácticas de acompañamiento, investigación biográfico-narrativa. E-mail: jramos@g.upn.mx 